\title{
МОДЕЛЬ ВПЛИВУ ФУНКЦІОНУВАННЯ І РОЗВИТКУ ВИЩОГО НАВЧАЛЬНОГО ЗАКЛАДУ НА СТАНОВЛЕННЯ ЕКОНОМІКИ ЗНАНЬ
}

\author{
Бойко Ганна Степанівна \\ аспірант \\ Вищий навчальний заклад Укоопспілки «Полтавський університет економіки і торгівлі» (м. Полтава, Україна) \\ ORCID0000-0003-0839-8407 \\ ludad5846@gmail.com
}

\begin{abstract}
В галузі освіти актуальним завданням є пошук управлінських рішень для розв'язання проблем, що постають перед вищими навчальними закладами в процесі їх функціонування та розвитку. Це пов'язано з інтеграцією ринкових відносин 8 систему вищої освіти, яка розширює межі автономії і самостійності вищих навчальних закладів. В дослідженні розроблено модель впливу функціонування і розвитку вищого навчального закладу на становлення економіки знань. Модель грунтується на застосуванні процесного підходу як інструменту розвитку вищого навчального закладу. Охарактеризовано державну політику у сфері вищої освіти, проаналізовано кількісні показники оцінки діяльності вищих навчальних закладів.
\end{abstract}

Ключові слова: вищий навчальний заклад, економіка знань, освіта, знання, розвиток.

DOI: https://doi.org/10.32845/bsnau.2019.2.14

Постановка проблеми. Особливості ринкової економіки зумовили принципово нові умови функціонування вищих навчальних закладів, що змінюють ключові основи розвитку системи вищої освіти. Перед суб'єктами управління вищих навчальних закладів постає завдання ідентифікації, оцінки та регулювання факторів, що впливають на їх розвиток, із наступним врахуванням їх у стратегії сталого розвитку.

Дослідженню теоретичних та практичних проблем функціонування і розвитку вищих навчальних закладів (ВН3) присвячено праці таких науковців, як А. Ашкеров, Г. Бекер, М. Блаут, Т. Боголіб, В. Бородюк, Х. Боуен, А. Віфлеємський, О. Грішнова, Е. Денісон, Г. Дмитренко, В. Жамін, В. Іноземцев, С. Костанян, В. Кремень, В. Куценко, В. Луговий, Я. Мінсер, В. Новіков, Г. Псахаропулос, Дж Стігліц, О. Сухарєв, В. Чекмарьов тощо.

Проте, інтеграція ринкових відносин в систему вищої освіти розширює межі автономії і самостійності вищих навчальних закладів. Тому актуальним завданням $€$ пошук управлінських рішень для розв'язання проблем, що постають перед вищими навчальними закладами в процесі їх функціонування та розвитку.

Мета статті. Визначення впливу функціонування і розвитку ВНЗ на становлення економіки знань. Досягнення названої мети дослідження відбулося за рахунок виконання таких завдань: характеристика державної політики України у сфері вищої освіти, аналіз кількісних показників оцінки діяльності ВН3, розробка моделі впливу функціонування і розвитку ВН3 на становлення економіки знань, яка розглядає процесний підхід як інструмент розвитку ВНЗ.

Виклад основного матеріалу. Державну політику у ссрері вищої освіти визначає Верховна Рада України, а реалізують Президент України, Кабінет Міністрів України та центральний орган виконавчої влади у сфері освіти і науки. Чинна Конституція України визначила право громадян України на здобуття освіти. Відповідно до Конституції України (стаття 53), кожен має право на освіту і держава забезпечує доступність і безоплатність дошкільної, повної загальної середньої, професійно-технічної, вищої освіти в державних і комунальних навчальних закладах; розвиток дошкільної, повної загальної середньої, позашкільної, профресійно-технічної, вищої

та післядипломної освіти, різних форм навчання; надання державних стипендій, пільг учням і студентам. Громадяни України вільні у виборі ВН3, форми здобуття вищої освіти і спеціальності.

Щоб забезпечити цю норму права на засадах фрілососрії якості і принципу постійного удосконалення, в результаті генезису нормативно-правового забезпечення у сфері вищої освіти, було створено єдину систему регламентації діяльності вищих навчальних закладів на основі процедур їх ліцензування, акредитації та атестації, упроваджено державні й галузеві стандарти вищої освіти, сформовано і впроваджено процедури контролю за організацією діяльності ВН3. Законодавство України про вищу освіту базується на Конституції України і складається із законів України «Про освіту», «Про вищу освіту», «Про наукову і науково-технічну діяльність», інших нормативно-правових актів та міжнародних договорів України.

Досягнення цілей ВН3, їх функціонування і розвиток відбувається за наявності фінансових ресурсів, в тому числі і бюджетних. У відносних показниках (питома вага витрат на освіту у ВВП) зведений бюджет України у частині освіти за світовими стандартами є достатньо високим (більше $5 \%$ ВВП), абсолютні ж обсяги ВВП України є значно нижчими за відповідні показники європейських країн.

На початок 2016-17 навчального року, відповідно до звіту Державної служби статистики, в Україні функціонували $657 \mathrm{BH} 3$, у яких навчалось 1587000 студентів. Впродовж 2010-2017 рр. спостерігається тенденція зниження кількості студентів ВН3, скорочення мережі ВН3, чисельності науково-педагогічного персоналу, що пов'язано з зниженням обсягу студентського контингенту та загостренням економічної кризи (табл.1).

Дані табл.. 1 відображають результати демографічної ситуації, а саме зниження кількості молоді, що народилася у 1993-2005 pр., зростання можливостей навчання за кордоном. Мережа вищих навчальних закладів скорочується за рахунок зменшення кількості ВНЗ I рівня акредитації у зв'язку з їх включенням до складу ВН3 III-IV рівнів акредитації у якості структурних підрозділів, динамічними темпами зменшується кількість ВНЗ приватної форми власності. 
Характеристика вищих навчальних закладів України [складено автором за 1; 2; 3]

\begin{tabular}{|c|c|c|c|c|c|c|}
\hline \multirow{2}{*}{ Показник } & \multicolumn{6}{|c|}{ Навчапьні роки } \\
\hline & $2010-2011$ & $2011-2012$ & $2012-2013$ & $2013-2014$ & $2014-2015$ & $2015-2016$ \\
\hline 1. Кількість ВНЗ, всього, од. & 813 & 805 & 785 & 767 & 664 & 659 \\
\hline $\begin{array}{c}\text { у тому числі за формами власності } \\
\text { державна та комунальна }\end{array}$ & 637 & 633 & 619 & 609 & 520 & 525 \\
\hline приватна & 176 & 172 & 166 & 158 & 144 & 134 \\
\hline 2. Кількість студентів, всього, осіб & 2418111 & 2246363 & 2106174 & 1992882 & 1689226 & 1605270 \\
\hline 3. Прийнято студентів, усього, осіб* & 506486 & 409541 & 427874 & 428356 & 361110 & 323064 \\
\hline 4. Випущено студентів, усього, осіб & 636291 & 609033 & 595251 & 560381 & 484482 & 447418 \\
\hline $\begin{array}{l}\text { 5. Кількість студентів у розрахунку на } 10000 \text { населення } \\
\text { станом на } 1.01 \text { відповідного року }\end{array}$ & 557 & 519 & 488 & 463 & 393 & 375 \\
\hline
\end{tabular}

* - прийнято осіб на початковий цикл навчання (без тих, що прийняті для продовження навчання з метою здобуття більщ високого освітньокваліфікаційного рівня);

** - випущено фрахівців (без тих, що закінчили відповідний цикл навчання, зокрема бакалаврат, та продовжують навчання з метою здобуття більш високого освітньо-кваліфікаційного рівня)

ЮНЕСКО розроблена Міжнародна стандартна класифікація освіти (МСКО), що являє собою всеохоплюючий статистичний опис національних систем освіти та методології їх порівняно з відповідними міжнародними рівнями. Розподіл споживачів послуг ВНЗ України за МСКО наведено в табл. 2.

Ключовою метою функціонування ВНЗ $є$ підготовка кадрів для реалізації трансформацій у суспільстві з метою забезпечення конкурентоздатності економіки, підвищення якості життя населення. Цьому має сприяти формування і впровадження ефективної системи управління освітніми закла- дами, яка б відповідала інтересам держави, потребам розвитку кожної особистості і суспільства в цілому.

Світові тенденції інноваційного розвитку спонукають ВН3 до формування випереджувальної моделі подальшого розвитку, яка суттєво вплине на національну систему освіти, що обумовлено спрямованістю державної політики на інтеграцію української системи вищої освіти у світову. Вирішення цієї проблеми переважним чином залежить від організації управління системою вищої освіти країни, та ВН3 зокрема (правильності вибору управлінських стратегій, своєчасності та ефективності управлінських рішень тощо).

Таблиия 2

Розподіл споживачів послуг вищих навчальних закладів України за міжнародною стандартною класифікацією освіти (МСКО) [складено автором за 1; 2; 3], (осіб)

\begin{tabular}{|c|c|c|c|c|c|c|c|}
\hline \multirow{2}{*}{$\begin{array}{l}\text { Назва ступеня освіти за } \\
\text { МСКО / код ступеня }\end{array}$} & \multirow{2}{*}{$\begin{array}{c}\text { Навчальні заклади, які забезпечують } \\
\text { отримання ступеня, тривалість } \\
\text { навчання }\end{array}$} & \multicolumn{5}{|c|}{ Навчальні роки } & \multirow{2}{*}{$\begin{array}{c}\text { Абсолютне відхилення } \\
\text { 2014-2015 н.р. від } \\
\text { 2010-2011 н.р. } \\
\end{array}$} \\
\hline & & $2010-2011$ & 2011-2012 & 2012-2013 & 2013-2014 & 2014-2015 & \\
\hline $\begin{array}{l}\text { Перший етап вищої } \\
\text { освіти - } 5 \text { A }\end{array}$ & $\begin{array}{l}\text { ВН3 III-IV рівнів акредитації, 5- } \\
6 \text { років }\end{array}$ & 2066667 & 1899138 & 1770311 & 1673287 & 1437955 & -628712 \\
\hline $\begin{array}{l}\text { Перший етап вищої } \\
\text { освіти - 5B }\end{array}$ & $\begin{array}{l}\text { ВНЗ I-II рівнів акредитації, 2-3 } \\
\text { роки }\end{array}$ & 351444 & 347225 & 335863 & 319595 & 251271 & -100173 \\
\hline $\begin{array}{l}\text { Другий етап вищої } \\
\text { освіти - 6 }\end{array}$ & $\begin{array}{l}\text { Аспірантура, докторантура, } 3 \\
\text { роки }\end{array}$ & 35271 & 34919 & 34581 & 32535 & 29381 & -5890 \\
\hline
\end{tabular}

Зростання конкуренції між ВНЗ, посилення вимог зацікавлених сторін - держави, студентів і роботодавців до якості освітніх послуг призвели до того, що орієнтація на споживача стає ключовим принципом в організації освітнього процесу. Для розробки дієвого механізму реагування на вимоги необхідна система управління якістю, що ґрунтується на процесному підході до управління і орієнтована на задоволення потреб споживачів освітніх послуг. Тому в дослідженні автором розроблено модель впливу функціонування і розвитку ВНЗ на становлення економіки знань, яка розглядає процесний підхід як інструмент розвитку ВН3 (рис. 1).

В умовах економіки знань, управління ВН3 - це перш за все управління процесом його розвитку. Освітня діяльність, яку здійснює ВНЗ, в умовах економіки знань є засобом виробництва знань, умінь і навичок. У розвинутих країнах саме ця сфрера економічної діяльності визначає їх конкурентоздатність.
Висновки. Сучасні динамічні трансформації суспільного розвиток у XXI столітті визначаються розвитком вищої освіти. Вищі навчальні заклади забезпечують розвиток національної економіки на інноваційних засадах, що визначається низкою провідних вітчизняних та іноземних учених як єдиний шлях розвитку будь-якої країни в глобалізованому конкурентному середовищі. Досягнення конкурентоспроможності ВНЗ можливо досягти за рахунок впровадження інноваційної моделі розвитку, яка дозволить впроваджувати зміни в навчальний процес у відповідності до вимог соціально-економічних та технологічних факторів зовнішнього середовища, а також відповідно до реальних і потенційних потреб споживачів освітніх послуг. Таким ключовим принципи інноваційних технологій освіти повинен відповідати розвиток інноваційноактивної особистості науково-педагогічних кадрів і студентів вищої школи, що і $є$ перспективою для подальших розвідок у даному напрямку досліджень.

\section{Список літератури:}

1. Основні показники діяльності вищих навчальних закладів України на початок 2015/16 навчального року [статистичий бюлетень за ред. О.О. Кармазіна] - К.: Державна служба статистики України, 2016. - 171 с.

2. Радченко О. В. Державна політика й управління в освіті: [підручник]. / О. В. Радченко, А. Є. Тамм, О. В. Поступна. - 
Х. : Вид-во Асоціації докторів державного управління, 2011 - 272 с.

3. Сисоєва С.О. Вища освіта України: реалії сучасного розвитку [монографія] / С.О. Сисоєва, Н.Г. Батченко / Міністерство освіти і науки, молоді та спорту України, Київський університет імені Бориса Грінченка, Національний університет біоресурсів та природокористування України - К. : ВД ЕКМО , 2011. - 368 с.

Boyko Anna, PhD student, Higher Educational Establishment of Ukoopspilka «Poltava University of Economics and Trade» (Poltava, Ukraine)

Model of influence of functioning and development of a higher educational institution on the formation of knowledge economy

In the field of education, the actual task is to seek managerial solutions to solve problems faced by higher education institutions in the process of their functioning and development. This is due to the integration of market relations into the system of higher education, which extends the boundaries of autonomy and autonomy of higher education institutions.

The research developed a model of the impact of the functioning and development of a higher educational institution on the formation of a knowledge economy. The model is based on the application of the process approach as an instrument for the development of a higher education institution. The state policy in the field of higher education has been characterized, quantitative indicators of evaluation of activity of higher educational institutions are analyzed.

Keywords: higher education institution, economics of knowledge, education, knowledge, development.

Дата надходження до редакції: 02.02.2019 p. 